Creative Commons User License: CC BY-NC-ND

Abstracted by: EBSCOhost, Electronic Journals Service (EJS),

Google Scholar, Journal Seek, Scientific Commons,

Food and Agricultural Organization (FAO), CABI and Scopus

http://eoi.citefactor.org/10.11226/v24i3
Journal of Agricultural Extension

Vol. 24 (3) July, 2020

ISSN(e): 24086851; ISSN(Print); 1119944X

http://journal.aesonnigeria.org

http://www.ajol.info/index.php/jae

Email: editorinchief@aesonnigeria.org

\title{
Effects of Food Price Shocks on Dietary Composition of Farm Households' in Nigeria \\ https://dx.doi.org/10.4314/jae.v24i3.3
}

\section{Adekunle, Chioma Patricia}

Department of Agricultural Economics and Farm management, Federal University of Agriculture, Abeokuta, Nigeria. Email: chiomaadekunle@gmail.com; phone: +2348060174180

\section{Kutu, Augustine Adebayo}

School of Accounting, Economics \& Finance, University of KwaZulu-Natal, South Africa.

Corresponding Author Email: kutuA@ukzn.ac.za; phone: +27712387450

\section{Alori, David Alaba}

Department of Agricultural Economics \& Extension, Federal University of Agriculture, P.M.B 65, Minna, Nigeria. Email: david alori@yahoo.com; phone: +2348060095870

\section{Abstract}

This study examined the effects of food price spikes on the quantity and quality of the dietary composition of farm households in Nigeria using the 2010/2011, 2012/2013 and 2015/2016 household survey panel data. The fixed effects models were estimated while controlling for participation in non-farm livelihood activities. Analysis indicated that seasonal comparisons of the average per capita daily calorie intake is lowest in the post-harvest season of 2011 (2511.44 kilocalories), which is higher than the average recommended intake. Results showed that rural households had lower per capita calorie intake and dietary diversity than urban households, which may be an indication of a shift in the calorie inadequacy from urban to rural farm households' setting in Nigeria. In addition, income and education improvement are crucial for raising food calories and satisfaction of hunger needs among households with total food consumption expenditure of $79.0 \%$. The study recommended that a combination of policy strategies, including income growth, agricultural development and targeted food distribution programs could reduce the problems of inadequate calorie consumption among farm households.

Keywords: Food price increase, household, nutrition, dietary diversity

\section{Introduction}

The 2007/2008 dramatic global food price upsurges and the recovery of 2010/2011 have kept the welfare effects of food price shocks at the center of policy discussions across the world. The effects of the food price shocks on household's nutrition 
Creative Commons User License: CC BY-NC-ND

Abstracted by: EBSCOhost, Electronic Journals Service (EJS),

Google Scholar, Journal Seek, Scientific Commons,

Food and Agricultural Organization (FAO), CABI and Scopus

http://eoi.citefactor.org/10.11226/v24i3
Journal of Agricultural Extension

Vol. 24 (3) July, 2020

ISSN(e): 24086851; ISSN(Print); 1119944X

http:///ournal.aesonnigeria.org

http://www.ajol.info/index.php/jae

Email: editorinchief@aesonnigeria.org

motivated additional discussions in this regard. When food prices increase, poorest households, that spend a large share of their income on food, are forced to reduce the quality and the quantities of food consumed leading to increased food insecurity at the household level (Headey and Martin, 2016). Studies have identified food shortage as a major consequence of food price inflation and price volatility (Jolliffe, Seff and De La Fuente, 2018). However, if the situation is coupled with the decline in global economic conditions, the world agricultural prices will continue to maintain an upward and volatile trend thereby exerting considerable hardship on the poor. For instance, Food and Agriculture Organization (2017) estimates that of the 7.6 billion people in the world in 2016, about 815 million people or $10.7 \%$ experience hunger. About 705 million people were estimated to be living in extreme poverty as a result of rising food prices (Roser and Ortiz-Ospina, 2017).

Food inflation in Nigeria has witnessed dramatic changes in recent years, reaching a peak of 20.32\% in September 2017 (CBN, 2018). In Nigeria, food price inflation is a critical economic problem posing threats to the poor who constitute the large proportion of the population. The average household in Nigerian spends about $73 \%$ of their income on food and beverage (Onyewuchi, 2016). Similarly, recent figures reported by Egwuma, Ojeleye and Adeola (2019) show that Nigerians spend $58.9 \%$ of their household income on food. This figure, which represents the highest in the world, implies that Nigerians spend over half of their income on food. This situation is made worse in the light of recent economic deterioration which has placed Nigeria as the country with the largest number of extremely poor people, with about 87 million people living in extreme poverty and six people becoming extremely poor every minute (Kharas, Hamel and Hofer 2018). Thus, the ability of the poor households to hedge against inflation especially regarding agricultural commodities is significantly hampered, leading to productivity losses and severe malnutrition (Rehman and Khan 2015).

Juarez-Torres (2015) posited that the burden of food price increases is borne more by the poor and vulnerable households who spend up to $80 \%$ or more of their earnings on foodstuffs. When households face massive negative price or income shocks, reduction in food budget is often their most immediate response (Baker, 2015). This manifests in compromised dietary intakes in terms of quantity and quality, which ultimately engender higher vulnerability to food insecurity, malnutrition, poverty and related issues. Available statistics on malnutrition in Nigeria show that incidences of stunting among under-five children in the country are approximately 32\% (Akombi, 2017), with the situation of hunger in the county still being rated as "serious" from international standpoint (Von Grebmer, Bernstein, Prasai, Yin, and Yohannes, 2015). Previous studies have placed the incidence of household food insecurity in the country between $49 \%$ and $78 \%$ based 
Creative Commons User License: CC BY-NC-ND

Abstracted by: EBSCOhost, Electronic Journals Service (EJS),

Google Scholar, Journal Seek, Scientific Commons,

Food and Agricultural Organization (FAO), CABI and Scopus

http://eoi.citefactor.org/10.11226/v24i3
Journal of Agricultural Extension

Vol. 24 (3) July, 2020

ISSN(e): 24086851; ISSN(Print); 1119944X

http://journal.aesonnigeria.org

http://www.ajol.info/index.php/jae

Email: editorinchief@aesonnigeria.org

on food calorie intake (Abbasi, Ghoochani, Ghanian and Kitterlin, 2016). It has also been found that a large proportion of households in the country consume less varied and low-quality foods (Agada and Igbokwe, 2015 and Akerele, 2015). The fundamental challenges to human welfare and economic growth in Africa is food and nutrition security especially with the recent spikes of food prices, a situation that is making the world to be facing a worsening food crisis unseen in the last 30 years and having the potential of leading to catastrophe (Juarez-Torres, 2015 and Grabowski and Self, 2016).

The role of economic shocks, particularly as price shocks however, is only analyzed in a few studies that mostly compare differences in food and nutrition security indicators (Kalkuhl, 2016). There have been a few attempts to estimate the impacts of the 2007/08 price changes on food and nutrition security. Based on the FAO approach to calorie deficit consumption, Bühler, Grote, Hartje, Ker, Lam, Nguyen and Tong (2015) calculated the livelihood of an additional 63 million individuals that became undernourished as a result of global food price spikes. Also, Yu and Shimokawa (2016) analyzed the impact of price increases on the number of calorie deficit people in African countries. They found that in most of the considered countries (including Nigeria), calorie deficiency increased for the poorest households, both in rural and urban areas.

Alem (2015) investigated which types of households in urban Ethiopia changed their food consumption significantly in 2008 when food prices were very high by investigating changes in consumption over three survey rounds in 2000, 2004 and 2008. They found that the high food price inflation was the most adverse economic shock between 2004 and 2008, and that a significant proportion of households adjusted food consumption in response to the price shocks. Their results indicated that households with low asset levels and casual workers were particularly adversely affected by high food prices.

In Nigeria, a few studies have been done in this area. Shittu, Akerele, and Haile (2018) examined the welfare effects of food price spikes among households in the country. They found that higher spike in the price of cereals consistently has negative effect on food quantities (including calories) consumed, dietary diversity, and economic welfare of households, spikes of price of other staples such as animal proteins, fats and oils, fruits and vegetables exert heterogeneous influence. This study is related to the Shittu, Akerele, and Haile (2018) but differs in the number of waves used in the panel data and the food groups by disaggregating cereals into three groups which were rice, wheat and other cereals. This is because the country has a structural deficit for these two grains, rice and wheat. Besides, rice and wheat accounted for a larger mean value in cereal consumption expenditure. Adekunle (2020) examined the welfare effects of food price changes on farm households in Nigeria and found a larger share $(79 \%)$ of farm households as net food buyers and cereal was identified as food for which the households were most vulnerable to price shocks. When adjustments are allowed, 
Creative Commons User License: CC BY-NC-ND

Abstracted by: EBSCOhost, Electronic Journals Service (EJS),

Google Scholar, Journal Seek, Scientific Commons,

Food and Agricultural Organization (FAO), CABI and Scopus

http://eoi.citefactor.org/10.11226/v24i3
Journal of Agricultural Extension

Vol. 24 (3) July, 2020

ISSN(e): 24086851; ISSN(Print); 1119944X

http:///ournal.aesonnigeria.org

http://www.ajol.info/index.php/jae

Email: editorinchief@aesonnigeria.org

households can adapt their consumption and production patterns resulting in lower deteriorations in welfare with significant differences across quintiles.

Conversely, little is known about the potential impacts of food price spikes on nutritional outcomes of households in Nigeria. Such information is crucial for the development of policies and programmes targeted at the improvement of well-being of households in the country. The highlighted concerns provide the motivation for this study. The study therefore seeks to address the following specific questions: How do food commodity price spikes affect the nutritional outcomes of households in Nigeria? Findings from this study can provide useful information for redesigning existing policy actions and programmes or for the introduction of new ones for improved living conditions of farm households in Nigeria.

This study becomes very important by the fact that the Sustainable Development Goals (SDGs) adopt nutritional status as one of the key indicators of poverty and hunger. It serves as the first step in recognizing that policies, programmes and processes to improve nutritional outcomes have a role to play in global development. Nutritional assessment in the community is essential for accurate planning and implementation of intervention programmes to reduce morbidity and mortality associated with undernutrition (Ghosh-Jerath, Singh, Lyngdoh, Magsumbol, Kamboj and Goldberg, 2018).

The rest of the article is as follows. The next section describes the data and presents the empirical model. Section 3 presents the results and discussion and section 4 concludes the study.

\section{Methodology}

This study was conducted in Nigeria using two types of quantitative data: household level panel consumption data from the general household survey (GHS) for 2010/2011, $2012 / 2013$ and 2015/2016 post-planting and post-harvest agricultural seasons. The World Bank/National Bureau of Statistics (NBS), Nigeria, collected the data. The panel survey was targeted to cover a total of 5,000 households selected from rural and urban areas of the 36 states of the country. The data covered different aspects of household livelihoods. Parts of the data that are relevant to this study are data on socioeconomic characteristics of the household and household head namely household size, age, sex, marital status, education of household head, location (rural-urban), season (postplanting or post-harvest seasons), whether or not a household engages in agriculture as main source of income. 
Creative Commons User License: CC BY-NC-ND

Abstracted by: EBSCOhost, Electronic Journals Service (EJS),

Google Scholar, Journal Seek, Scientific Commons,

Food and Agricultural Organization (FAO), CABI and Scopus

http://eoi.citefactor.org/10.11226/v24i3
Journal of Agricultural Extension

Vol. 24 (3) July, 2020

ISSN(e): 24086851; ISSN(Print); 1119944X

http://journal.aesonnigeria.org

http://www.ajol.info/index.php/jae

Email: editorinchief@aesonnigeria.org

The second data set were price data, which are monthly time series (2010:1 - 2016:12). The retail commodity prices across the panel of 36 states and the Federal Capital Territory obtained from National Bureau of Statistics Headquarter office in Abuja. The food items are imported rice, local rice, maize, sorghum, millet, beef (meat), fish, egg, yam, garri, beans, and palm oil. These specific food items are very critical to household food security in the country, as they constitute important components of household diets.

In order to construct a measure of dietary diversity, food items were grouped into fourteen (14) which is in line with Hirvonen, Taffesse and Hassen (2016). The study follows a more conventional approach to eliminate bias and exclude all observations within each commodity group with values below and above the 1st and the 99th percentiles. However, only 23,039 households with the complete set of information required after data cleaning and appearing in all the three rounds of data collection were included in this study. Hence, the final panel was made up of 23,039 observations, consisting of data collected from 3921 households in 2010, 3886 households in 2011, 3869 households in 2012, 3959 households in 2013, 3734 households in 2015 and 3670 households in 2016 respectively.

\section{Variables Measurement}

Index of food consumption: Expenditure weighted food price index, and all items price index were required to divide the value of food consumed and the total household expenditure respectively. Consequently, Tornqvist-Theil price index (which is an expenditure-weighted price index) was computed for food as well as all items (food and non-food items). Doing this could better adjust for the possible varying effects that changes in prices might have on household food consumption over time and across locations. The Tornqvist-Theil index is a superlative index that utilizes expenditure and price data from the two domains, i.e. base location/time period and new location/time period. As mentioned earlier, food items were classified into fourteen groups and nonfood items were classified into 2 groups. This makes a total of sixteen groups for all items (food and non-food items).

Two key dependent variables used in this study were the quantities of food calories consumed and dietary diversity.

Calorie intake estimation: Data on the quantities of food consumed were standardized per kilogramme using the conversion factors of local units to the standard unit provided in the Living Standard Measurement Study (LSMS) survey manual. The calorie content 
Creative Commons User License: CC BY-NC-ND

Abstracted by: EBSCOhost, Electronic Journals Service (EJS),

Google Scholar, Journal Seek, Scientific Commons,

Food and Agricultural Organization (FAO), CABI and Scopus

http://eoi.citefactor.org/10.11226/v24i3
Journal of Agricultural Extension

Vol. 24 (3) July, 2020

ISSN(e): 24086851; ISSN(Print); 1119944X

http:///ournal.aesonnigeria.org

http://www.ajol.info/index.php/jae

Email: editorinchief@aesonnigeria.org

of each food was obtained by multiplying food quantity by its calorie conversion factor (per kg). According to Rischke, (2015), the per capita calorie consumption of household ' $\mathrm{j}$ ' in time ' $\mathrm{t}$ ' is estimated given the specified formula:

$C I_{i t}=\sum_{k=1}^{n} B_{k i t} A_{k} / Z_{i t}$

where $C I_{i t}$ is the per capita daily quantity (amount) of calorie consumed by household 'i' at time t. $B_{\text {kit }}$ is weight in kilogramme of food item ' $\mathrm{k}$ ' consumed by household $\mathrm{i}$ at time $\mathrm{t}$, and $A_{k}$ is the standardized nutrient content per kilogramme of food commodity k. $Z_{i t}$ is the number of people in household ' $i$ ' at time ' $t$ '. In line with Harttgen, Klasen and Rischke (2016), households with per capita daily calorie consumption below 500 and above 12000 kilocalories were removed as outliers.

Food consumption dietary diversity: The Dietary Diversity Score (DDS) estimates the rate at which the variety of food consumed by households differs in terms of nutrient intakes over a given period. The DDS suggests that households gain satisfaction on food consumed not only because "more is better", but because 'variety' is the spice of life. According to Ogundari (2017), higher DDS implies that a household is consuming a diet that is diverse, and whose quality is sufficient to supply important micronutrients. According to Obwanga, Rurangwa, van Duijn, Soma and Kilelu (2018), DDS represents the food utilization dimension of the food security. Desiere, D'Haese and Niragira (2015) also referred to DDS as an effective indicator of food utilization for two reasons. First, it reflects consumption of both macro- and micronutrients. Second, demand theory suggests that individuals or households that allocate their resources towards higherquality foods when they have satisfied their basic caloric needs attain a higher level of utility. However, a major limitation of DDS is that it fails to account for the quantity of nutrient consumed by the households.

Household demand for Dietary Diversity (DD) has always been modeled in the literature with either DDS, which represents count data, or DDI that represents indices. For example, Vadiveloo, Parkeh and Mattei (2015) and Kim, Shin, Guevarra, Lee, Kim, Seol and Isaacson (2017) employed DDS, while Freire and Rudkin (2019) utilized DDI in their respective studies. Similar to the work of Freire and Rudkin (2019), the study constructed the DDI from household food expenditure, which has been aggregated across food groups using Berry index as follows: 
$D D I_{i t}=1-\sum_{g=1}^{F} S_{g i t}^{2}$

where DDI is as defined earlier and ranges between 0 and 1 , with a value towards 1 implying higher dietary diversity and $S_{\text {git }}$ is the food consumption share of food group ' $\mathrm{g}$ ' in the total value of food consumed by household ' $i$ ' in time ' $t$ ' and ' $F$ ' is the total number of food groups (Tian and Yu, 2015).

Food price spikes: The study constructed the expenditure weighted price spikes for the fourteen (14) aggregated food groups. First, a measure of price spike was constructed (for each food group) using the log return of the food group prices, across specific states, months and years that correspond to the household panel survey. The log return of the price of each food group was estimated for each of the months in each of the years covering January, 2010 to December, 2016. Following Tadasse, Algieri, Kalkuhl and Von Braun (2016), the price spike is specified as follow in a panel model:

$Q_{i m t}=\ln \left(\frac{P_{\text {imt }}}{P_{\text {imt-1 }}}\right)=\ln \left(P_{\text {imt }}\right)-\ln \left(P_{\text {imt }-1}\right)$

Where $P_{\text {imt }}$ is the average/proxy price for a food group in month ' $m$ ' of year ' $\mathrm{t}$ ' in a given state of the country. $P_{\text {imt-1 }}$ is the average/proxy price of the food group in the preceding month in the same state and year. Thereafter, each estimated spike ( $\left.Q_{i m t}\right)$ was weighted by the share of each food group in the total value of food consumed by each household as follows:

$D_{i j t}=S_{i j t} * R_{m t}$

Where $D_{i j t}$ the expenditure is weighed spike which better reflect the variation in price spikes across households over time. Data on food price spikes are merged (mapped) with the household panel data by state, year, and month of data collection.

Estimation model: To measure the impacts of price spikes on the quantity of food calories consumed and dietary diversity the quantity of food calories consumed and dietary diversity of the household at the individual level was specified as a function of the price spikes, as well as household and individual characteristics. The model specification of the quantity of food calories consumed and dietary diversity of household $i$, at year $t$, denoted by $Y_{i t}$, as follows: 
Creative Commons User License: CC BY-NC-ND

Abstracted by: EBSCOhost, Electronic Journals Service (EJS),

Google Scholar, Journal Seek, Scientific Commons,

Food and Agricultural Organization (FAO), CABI and Scopus

http://eoi.citefactor.org/10.11226/v24i3
Journal of Agricultural Extension

Vol. 24 (3) July, 2020

ISSN(e): 24086851; ISSN(Print); 1119944X

http://journal.aesonnigeria.org

http://www.ajol.info/index.php/jae

Email: editorinchief@aesonnigeria.org

$Y_{i t}=\beta_{0}+\beta_{1} P_{i t}+\beta_{2} X_{i t}+\mu_{t}+\eta_{t}+\varepsilon_{i t}$

Where $Y_{i t}$ is a measure of the logarithmic value of dimensions of household nutritional outcomes (the quantity of food calories consumed and dietary diversity), $P$ is a vector of price spikes variables, $X_{i t}$ is a vector of variables of households' characteristics, $\mu_{t}$ represents the time-invariant household's fixed effects (such as for example eating habits or food preferences), $\eta_{t}$ represents the year effects, and $\varepsilon_{i t}$ is the error term. This study assume that households' fixed effects can be captured by a separate constant for each household: the use of time-invariant household fixed effects is necessary to remove unobserved time-invariant factors at the household level. The failure to control for these household-specific attributes will produce omitted variable bias if the omitted factors are correlated with observed covariates.

The key control variables, other relevant explanatory variables were operationalized as follows: natural log of non-food price (computed from the non-food price); surplus season dummy ( 1 if data were collected from household in the harvest/post-harvest season, 0 if data were collected during lean/post-planting season); Urban dummy (1 if household is located in urban area, zero, otherwise); sex of household head dummy (1 if household head is a male, 0 otherwise); marital status of household head ( 1 if household head is married, 0 otherwise); age of household head (years); household headed by master/PhD degree holder ( 1 if household head has Master/PhD degree, 0 otherwise); household headed by First Degree holder (1 if highest formal educational attainment of household head is Higher National Diploma or First degree, 0 otherwise); household headed ( 1 if highest formal educational attainment of household head is ND/NCE holder, 0 otherwise); household headed by secondary school certificate holder ( 1 if highest formal educational attainment of household head is secondary school, 0 otherwise); household headed by primary ( 1 if highest formal educational attainment of household head is primary school, 0 otherwise) and income status of the household.

There were three dummy variables for the income status, reflecting relatively low, middle and high income status. For the middle income status dummy, household is assigned 1 if the household classified as belonging to middle income, otherwise zero. Likewise, for the high-income status group, household is assigned if the household is classified as having relatively high income, otherwise zero. For the dummy variables on education, the "no formal education household head group" was dropped, while for the income status dummies, the relatively "low income household group" was dropped from analysis. Participation in non-farm livelihood activities and proportion of households with under five year children. There are six dummy variables for the geo-political zone as also included in the analysis. 
Creative Commons User License: CC BY-NC-ND

Abstracted by: EBSCOhost, Electronic Journals Service (EJS),

Google Scholar, Journal Seek, Scientific Commons,

Food and Agricultural Organization (FAO), CABI and Scopus

http://eoi.citefactor.org/10.11226/v24i3
Journal of Agricultural Extension

Vol. 24 (3) July, 2020

ISSN(e): 24086851; ISSN(Print); 1119944X

http://journal.aesonnigeria.org

http://www.ajol.info/index.php/jae

Email: editorinchief@aesonnigeria.org

\section{Results and Discussion}

\section{Some Dimensions of Household Nutritional Outcomes}

Measures of nutritional outcomes were a measure of dietary diversity (a count of food groups covered by a household's reported consumption during the past week), and the number of calories consumed per Adult Equivalent Unit (AEU) over the past week. According to Akerele, Sanusi, Fadare and Ashaolu (2017), dietary diversity is a good predictor of child nutrition in particular as it captures the quality of the diet regarding micronutrients in contrast to using calorie consumption.

The amount of calories consumed are used as measures of the quantity dimension of food security (access to food). Dietary diversity is used as a proxy of the quality of diets. (Table 1). Food consumption, in terms of kcal/person/day, is the key variable used for measuring and evaluating the evolution of the world food situation. With respect to amount of calorie consumption, the observed pattern across seasons over the years covered by the study is that the average per capita daily calorie consumption is consistently higher during the post-harvest seasons than in the post-planting seasons for the three waves. The amount of dietary diversity seems to be higher in the first waves compared to the other two waves. Notwithstanding, the metric of dietary diversity for the post-harvest season (year 2011) is slightly higher $(0.78)$ than that $(0.76)$ of postplanting (2010) season.

The somewhat high dietary diversity recorded during the post-harvest period (of year 2011), might be associated with relatively higher real value of food consumed during the same season. This is because the quantity of food calories consumed during the period (season) is lower than the quantity consumed in the other periods. In the study of Akerele (2015), the direct correlation between consumption of more varied foods and likelihood of adequate intakes of food calories and nutrients in Nigeria is documented.

Seasonal comparisons of the average per capita daily calorie consumption indicated that it is lowest in the post-harvest season of 2011 (2511.44 kilocalories), this amount is higher than the average per capita daily calorie intake (2428 kilocalories) reported by Sibhatu and Qaim (2017) and lower than that the average per capita daily calorie intake (2936.99 kilocalories) of Shittu, Akerele, and Haile (2018). This is an evidence of dynamics in calorie supply/consumption in Nigeria in recent times compared to the past years. Likewise, the estimated calorie consumption (2511.44 kilocalories) per capita daily calorie consumed is still higher than the average recommended daily per capita calorie of 2500 kilocalories for developing countries (FAO, 2017). This means that on the average, household calorie consumption may still be adequate and enjoying higher level of dietary diversity during the period (2011) compared to other seasons (periods). 
Creative Commons User License: CC BY-NC-ND

Abstracted by: EBSCOhost, Electronic Journals Service (EJS),

Google Scholar, Journal Seek, Scientific Commons,

Food and Agricultural Organization (FAO), CABI and Scopus

http://eoi.citefactor.org/10.11226/v24i3
Journal of Agricultural Extension

Vol. 24 (3) July, 2020

ISSN(e): 24086851; ISSN(Print); 1119944X

http://journal.aesonnigeria.org

http://www.ajol.info/index.php/jae

Email: editorinchief@aesonnigeria.org

Table 1: Dimensions of household nutritional outcome

\begin{tabular}{|c|c|c|c|c|}
\hline & Mean & Standard Deviation & Minimum & Maximum \\
\hline \multicolumn{5}{|l|}{ Year 2010 (Post-Planting Season) } \\
\hline Daily Per capita calorie consumed & 2814.42 & 2208.17 & 484.04 & 15854.11 \\
\hline Dietary Diversity & 0.76 & 0.14 & 0.00 & 0.84 \\
\hline $\begin{array}{l}\text { Weekly Real per capita Value of Food } \\
\text { consumed }\end{array}$ & 897.43 & 816.79 & 42.18 & 16482.22 \\
\hline $\begin{array}{l}\text { Weekly Real per capita total } \\
\text { expenditure }\end{array}$ & 2112.02 & 5284.06 & 48.01 & 68112.28 \\
\hline \multicolumn{5}{|c|}{ Total number of households in $2010=3921$} \\
\hline \multicolumn{5}{|l|}{ Year 2011 (Post-Harvest Seasons) } \\
\hline Daily Per capita calorie consumed & 2511.44 & 2444.36 & 482.08 & 14632.16 \\
\hline Dietary Diversity & 0.78 & 0.14 & 0.00 & 0.84 \\
\hline $\begin{array}{l}\text { Weekly Real per capita Value of Food } \\
\text { consumed }\end{array}$ & 1158.54 & 883.72 & 51.28 & 19912.34 \\
\hline $\begin{array}{l}\text { Weekly Real per capita total } \\
\text { expenditure }\end{array}$ & 2153.32 & 4846.91 & \multirow[t]{2}{*}{55.04} & 56332.82 \\
\hline \multicolumn{4}{|c|}{ Total number of households in $2012=3886$} & \\
\hline \multicolumn{5}{|l|}{ Year 2012 (Post-Planting Season) } \\
\hline Daily Per capita calorie consumed & 2919.16 & 2172.28 & 612.44 & 12696.01 \\
\hline Dietary Diversity & 0.70 & 0.15 & 0.00 & 0.82 \\
\hline $\begin{array}{l}\text { Weekly Real per capita Value of Food } \\
\text { consumed }\end{array}$ & 1021.76 & 1005.04 & 44.26 & 16129.38 \\
\hline $\begin{array}{l}\text { Weekly Real per capita total } \\
\text { expenditure }\end{array}$ & 2562.82 & 5134.24 & 47.18 & 55199.06 \\
\hline \multicolumn{5}{|c|}{ Total number of households in $2012=3869$} \\
\hline \multicolumn{5}{|l|}{ Year 2013 (Post-Harvest Seasons) } \\
\hline Daily Per capita calorie consumed & 2886.18 & 2242.24 & 498.19 & 13441.36 \\
\hline Dietary Diversity & 0.73 & 0.15 & 0.00 & 0.82 \\
\hline $\begin{array}{l}\text { Weekly Real per capita Value of Food } \\
\text { consumed }\end{array}$ & 930.13 & 911.26 & 44.43 & 16672.65 \\
\hline $\begin{array}{l}\text { Weekly Real per capita total } \\
\text { expenditure }\end{array}$ & 2041.93 & 5152.43 & 49.16 & 56331.63 \\
\hline \multirow{2}{*}{\multicolumn{5}{|c|}{ Total number of households in $2013=3959$}} \\
\hline & & & & \\
\hline Daily Per capita calorie consumed & 2922.15 & 2246.43 & 508.47 & 12655.68 \\
\hline Dietary Diversity & 0.72 & 0.16 & 0.00 & 0.82 \\
\hline $\begin{array}{l}\text { Weekly Real per capita Value of Food } \\
\text { consumed }\end{array}$ & 1004.83 & 963.66 & 51.13 & 15322.67 \\
\hline \multirow[t]{2}{*}{$\begin{array}{l}\text { Weekly Real per capita total } \\
\text { expenditure }\end{array}$} & 1593.53 & 2217.01 & 52.28 & 61563.45 \\
\hline & \multicolumn{3}{|c|}{ Total number of households in $2015=3734$} & \\
\hline Year 2016 (Post-Harvest Season) & & & & \\
\hline Daily Per capita calorie consumed & 2651.96 & 2142.52 & 511.17 & 12882.13 \\
\hline Dietary Diversity & 0.64 & 0.16 & 0.00 & 0.82 \\
\hline $\begin{array}{l}\text { Weekly Real per capita Value of Food } \\
\text { consumed }\end{array}$ & 954.24 & 913.44 & 50.56 & 14849.75 \\
\hline \multirow[t]{2}{*}{$\begin{array}{l}\text { Weekly Real per capita total } \\
\text { expenditure }\end{array}$} & 2435.64 & 4490.45 & 53.32 & 69112.23 \\
\hline & \multicolumn{3}{|c|}{ Total number of households in $2016=3670$} & \\
\hline
\end{tabular}

Note: The percent of households with zero (0) values for dietary diversity are negligible. 
Creative Commons User License: CC BY-NC-ND

Abstracted by: EBSCOhost, Electronic Journals Service (EJS),

Google Scholar, Journal Seek, Scientific Commons,

Food and Agricultural Organization (FAO), CABI and Scopus

http://eoi.citefactor.org/10.11226/v24i3
Journal of Agricultural Extension

Vol. 24 (3) July, 2020

ISSN(e): 24086851; ISSN(Print); 1119944X

http://journal.aesonnigeria.org

http://www.ajol.info/index.php/jae

Email: editorinchief@aesonnigeria.org

\section{Effects of Food price spikes on Real Value of Food, Dietary Diversity and Calorie Consumed}

In Table 2, results of the influence of food price spike and other control variables on the real value of household and per capita calorie and dietary diversity are presented. Higher spikes in the price of rice, wheat, fats and oils, vegetables, eggs, fish, sweeteners, other foods among others, have significant reduction effects on per capita calorie household food consumption, whereas greater spikes in the price of pulses, fruits, can substantially increase per capita calorie food consumption.

Although higher spikes in the price of some foods such as other cereals, pulses, fish may affect the real value of food consumed, this may not necessarily reflect in improved diets as extreme food price shocks may constrain poor people (households) to shift to less-varied diets, which could have a harmful effect on their nutritional status in the short and long run (Weber, 2015). Findings suggest that higher spike in the price of meat is unlikely to influence the real value of food and calorie consumed whereas, the spikes in the price of fish influence the real value of food consumed due to improved diet. This can be attributed to cost (meat is more expensive) of meat compared to fish.

The results suggest that increase in general price of non-food items may have positive effects on the real value of food consumed but a negative effect on both the calorie consumed and dietary diversity. For households who are not into sales of non-food items, higher non-food prices is expected to diminish the purchasing power of the household. However, consumption of food may increase, particularly if household can no longer afford consumption of some non-food commodities due to reduced income as noted by Kalkuhl (2016).

The results of the effects of food price spikes and related factors on food consumption variety revealed that higher spikes in the price of wheat, other cereals, pulses, fruits, vegetables, meat, milk/dairy products, sweeteners, other foods enhance food consumption diversity while higher price in the price of rice, roots and tubers, fat and oil, eggs, and fish will reduce food consumption variety. Greater spikes in the price of roots and tubers, rice, and egg had a negative and significant relationship with household dietary diversity. However, the price spike of meat and beans/pulses established a positive and significant relationship with household dietary diversity.

On the basis of the estimated coefficients, the results suggest that food consumption diversity is more sensitive to changes in the price of roots and tubers than cereals and eggs. Roots and tubers and rice are generally calorie-rich foods which are needed to meet hunger needs of the people. Hunger satisfaction (through food calories) is arguably a fundamental (food) need, and an average household would first seek to gratify this before fulfilling other food nutrient needs such as proteins and vitamins. 
Creative Commons User License: CC BY-NC-ND

Abstracted by: EBSCOhost, Electronic Journals Service (EJS),

Google Scholar, Journal Seek, Scientific Commons,

Food and Agricultural Organization (FAO), CABI and Scopus

http://eoi.citefactor.org/10.11226/v24i3
Journal of Agricultural Extension

Vol. 24 (3) July, 2020

ISSN(e): 24086851; ISSN(Print); 1119944X

http://journal.aesonnigeria.org

http://www.ajol.info/index.php/jae

Email: editorinchief@aesonnigeria.org

Besides, rice, root and tubers accounted for $15.62 \%$ and $12.59 \%$ respectively in total food consumption expenditure of $79.0 \%$. This implies that households are still generally less willing to trade-off food diversity (quality) for quantity (calories) in the face of extreme spikes of rice and root and tubers price.

Ideally, the real per capita value of food consumed in urban households is unlikely to be substantially lower than rural households. However, results suggest that urban households had lower per capita calorie consumption than rural households. This may be indicative of a shift in the locus of caloric inadequacy from urban to rural farm households setting in the country. Rural households have a higher food consumption diversity than their urban counterpart. The rural households are expected to have direct access to what they cultivate and this could enhance dietary diversification (Weber, 2015), while urban households (non-agricultural households) can only purchase what is available in the market (Famine Early Warning Systems Network, 2017). Hence, households that are engaged primarily in agricultural production consumed more variety of foods than non-agricultural households as this is the case of rural farm households in Nigeria. The results further show that the demand for dietary diversity significantly increases among households headed by farmers in the study, in contrast to what was obtained by Freire and Rudkin (2019), where being a farmer means having decreased food diversity.

The coefficient associated with the male headed households has a statistically significant and negative effect on real value of food consumed and dietary diversity but a positive on food calorie consumed. This implies that the male headed households have a substantially higher real per capita food consumption compared to their female headed household counterparts. This is due to the fact that male is the head of the household and saddle with more responsibility that benefit all household members.

The coefficient of marital status of household head (married dummy) was statistically significant but has a positive impact on the real value of household per capita food consumption. This means that an average household headed by a married person has a higher value of per capita food consumption compared to other household groups. This is possible if such household has larger members, and, who do contribute substantially to raising household income. The coefficient of marital status of the household head is statistically significant with negative impact on household per capita daily calorie intake. This points out that households whose heads are married have lower per capita daily calorie consumption than the other household groups.

The results further show that age of household head has a significantly negative effect on calorie intake and positive effect on the real value of household per capita food consumption. This is probably because older people may not be able to afford adequate 
Creative Commons User License: CC BY-NC-ND

Abstracted by: EBSCOhost, Electronic Journals Service (EJS),

Google Scholar, Journal Seek, Scientific Commons,

Food and Agricultural Organization (FAO), CABI and Scopus

http://eoi.citefactor.org/10.11226/v24i3
Journal of Agricultural Extension

Vol. 24 (3) July, 2020

ISSN(e): 24086851; ISSN(Print); 1119944X

http://journal.aesonnigeria.org

http://www.ajol.info/index.php/jae

Email: editorinchief@aesonnigeria.org

nutrition intake. That is, the capacity to access sufficient calories declines with age. The results further show that the lower the age of the household head, the higher their demand for higher dietary diversity compared to household heads who are older. This is possible, because those that are younger have to consume as many nutritional foods as possible to be in the possession of the physical and mental capacities needed to engage in the education and labour activities (Ogundari, 2017).

The coefficients of educational dummies were positive, and statistically significant, pointing to the potential role that formal education gains could play in improving food consumption. The educational level of the household head, which can be taken as a proxy for consumer dietary knowledge and ability to process dietary information, had a significant negative relationship with the demand for dietary diversity. The positive and significant coefficients of educational dummies imply that having access to formal education is likely to promote food consumption diversity. This finding is in line with previous findings that found households whose heads are educated to have higher demand for dietary diversity as greater access to formal education is expected to reflect in better appreciation of the roles of more varied foods in enhancing diet quality (Pauzé, Batal, Philizaire, Blanchet and Sanou, 2016). Similar result of this study is found in Ogundari (2017). This outcome suggests that other factors beyond access to formal education might need to be considered to raise diversity of household diets.

The coefficient of surplus/post-harvest season is statistically significant and positively related to the real value of household per capita food consumption, calorie intake and dietary diversity. This implies that households also consumed more diverse foods during the post-harvest season (Farayibi and Owuru, 2016). This is because, supply and availability of food in the market are linked to seasonality and this can in turn influence food consumption patterns.

In addition, households classified in middle and relatively high income group had higher real per capital consumption than households in low income group. It is worthy of note that although price spikes may lead to reduction in food calories and real per capita value of food consumption (Genoni, Baez and Salazar, 2015), richer households are more likely to reduce calories than poorer ones (D'Souza and Jolliffe, 2016).

Nevertheless, extremely poor households (whose lives are characterized by inadequate calorie intakes) may be unable to substantially cut-back food quantity (calories), and would rather adjust the compositions of their diets to sustain their calorie intake (energy) levels. Again, household dietary diversity increases significantly as household income increases. High-income households have access to more varied diets than low income households (Daniel, 2016). At very low level of income, households spend a substantial amount of their income on necessities including staple foods. However, they tend to allocate more of their income to more diverse foods, and other goods and services as 
Creative Commons User License: CC BY-NC-ND

Abstracted by: EBSCOhost, Electronic Journals Service (EJS),

Google Scholar, Journal Seek, Scientific Commons,

Food and Agricultural Organization (FAO), CABI and Scopus

http://eoi.citefactor.org/10.11226/v24i3
Journal of Agricultural Extension

Vol. 24 (3) July, 2020

ISSN(e): 24086851; ISSN(Print); 1119944X

http://journal.aesonnigeria.org

http://www.ajol.info/index.php/jae

Email: editorinchief@aesonnigeria.org

their incomes increase. D'Souza and Jolliffe (2016), noted that richer households do normally consume more varied diet (of relatively more expensive foods); thus providing the opportunity to bias consumption towards cheaper (alternative) foods as prices increase (D'Souza and Jolliffe, 2016). This is consistent with the finding of Shittu, Akerele, and Haile (2018) for households in Nigeria, Kenya, and Ethiopia respectively. Our finding, according to Freire and Rudkin (2019), is consistent with the hypothesis

\section{Table 2: Food price shocks on food calorie consumption and dietary diversity}

\begin{tabular}{|c|c|c|c|c|c|c|}
\hline \multirow[b]{2}{*}{ Variable } & \multicolumn{2}{|c|}{ Food Calorie Consumed } & \multicolumn{2}{|c|}{$\begin{array}{l}\text { Real value of food } \\
\text { consumed }\end{array}$} & \multicolumn{2}{|c|}{ Dietary Diversity } \\
\hline & Coeff. & t-value & Coeff. & t-value & Coeff. & t-value \\
\hline Spike in price of Rice & $-0.18^{\star \star *}$ & 4.24 & $-0.26^{\star \star *}$ & -2.55 & $-0.22^{* \star *}$ & -2.92 \\
\hline Spike in price of Wheat & $-0.09^{\star *}$ & -2.45 & $-0.18^{\star * *}$ & 4.27 & $0.12^{\star \star \star}$ & 2.88 \\
\hline Spike in price of other cereals & 0.02 & 1.63 & $0.16^{\star *}$ & 2.17 & $0.03^{* *}$ & 2.16 \\
\hline Spike in price of roots and tubers & $-0.28^{* * *}$ & -3.13 & $-0.21^{\star \star *}$ & -4.23 & $-0.22^{* \star *}$ & -2.83 \\
\hline Spike in price of pulses & $0.32^{\star * *}$ & 2.56 & $0.15^{\star \star \star}$ & 2.88 & $0.24^{\star \star *}$ & 2.51 \\
\hline Spike in price of fats and oils & $-1.11^{* *}$ & -2.14 & 0.28 & 1.49 & 0.21 & 1.01 \\
\hline Spike in price of fruits & $1.21^{* * *}$ & 2.89 & $-4.18^{\star * \star}$ & -5.12 & $1.15^{\star *}$ & 2.18 \\
\hline Spike in price of price of vegetables & $-1.82^{* * *}$ & -3.42 & $-2.65^{\star \star *}$ & -2.94 & $2.03^{* * *}$ & 4.14 \\
\hline Spike in price of price of egg & $-0.06^{\star *}$ & -2.34 & 1.21 & 1.23 & $-1.25^{\star \star *}$ & -2.93 \\
\hline Spike in price of price of meat & 0.04 & 1.33 & 0.02 & 1.43 & $0.03^{*}$ & 1.94 \\
\hline Spike in price of price of fish & $-0.02^{\star}$ & -1.80 & $0.23^{* * *}$ & 3.44 & -0.02 & -0.16 \\
\hline Spike in price of price of milk/dairy & 0.21 & 1.11 & $-1.66^{* *}$ & -2.48 & $0.32^{* * *}$ & 4.94 \\
\hline Spike in price of sweeteners & $-1.03^{* * *}$ & -4.12 & $-1.26^{*}$ & -1.94 & $1.23^{\star *}$ & 2.33 \\
\hline Spike in price of price of other foods & $-1.15^{\star * *}$ & -2.66 & 2.22 & 1.18 & $1.31^{\star *}$ & 2.28 \\
\hline Natural log of non-food price & $-0.08^{\star \star}$ & -2.18 & $0.11^{* * *}$ & 4.16 & $-0.08^{*}$ & -1.86 \\
\hline Location (Urban dummy) & $0.02^{* *}$ & 2.44 & $-0.04^{* * *}$ & -5.54 & $-0.02^{\star * *}$ & -2.74 \\
\hline Sex (Male Headed Household dummy) & $0.24^{* * *}$ & 4.16 & $-0.18^{\star \star *}$ & -5.62 & $-0.21^{\star * \star}$ & -3.13 \\
\hline $\begin{array}{l}\text { Marital status of household head (married } \\
\text { dummy) }\end{array}$ & $-0.02^{\star \star *}$ & -3.22 & $0.08^{* * *}$ & 4.04 & 0.33 & 0.43 \\
\hline Age of household head & $-0.18^{* * *}$ & -3.14 & $0.02^{* * *}$ & 3.83 & $-0.03^{*}$ & -1.88 \\
\hline Household headed by master/PHD holder & 0.03 & 1.12 & -0.02 & -0.11 & $-0.02^{*}$ & -1.76 \\
\hline Household headed by First Degree holder & 0.14 & 0.68 & $0.02^{* *}$ & 2.16 & $-0.02^{\star \star *}$ & -2.54 \\
\hline Household headed by OND holder & 0.03 & 1.33 & $0.01^{* * *}$ & 3.12 & $-0.04^{* * *}$ & -3.67 \\
\hline $\begin{array}{l}\text { Household headed by secondary school } \\
\text { certificate holder }\end{array}$ & $0.02^{\star \star *}$ & 2.52 & $0.02^{\star * *}$ & 3.88 & $-0.02^{\star * *}$ & -2.55 \\
\hline Household headed by primary school holder & $0.16^{\star \star *}$ & 2.02 & 0.21 & 0.44 & $-0.03^{* * *}$ & -4.74 \\
\hline Season (Post-Harvest/Surplus) & $0.03^{* * *}$ & 3.43 & $0.02^{* * *}$ & 3.33 & $0.01^{* *}$ & 2.23 \\
\hline Middle income household & $0.22^{\star *}$ & 2.35 & $0.16^{\star * *}$ & 3.27 & $0.02^{* * *}$ & 4.12 \\
\hline High income household & $0.13^{\star * *}$ & 2.02 & $1.18^{\star * *}$ & 2.88 & $0.04^{* * *}$ & 3.91 \\
\hline Non-Farm (Participation dummy) & $-0.22^{* *}$ & -2.18 & $0.23^{* *}$ & 2.22 & $0.25^{* * *}$ & 2.84 \\
\hline $\begin{array}{l}\text { Dependency dummy (households with } \\
\text { under five year children) }\end{array}$ & $1.26^{* * *}$ & 2.73 & $0.44^{* * *}$ & 4.17 & $0.24^{* * *}$ & 2.24 \\
\hline Zone (North central dummy) & $-0.24^{* *}$ & 2.22 & -0.01 & 1.23 & $0.08^{*}$ & 1.94 \\
\hline Zone (North west dummy) & 0.15 & 1.63 & 0.08 & 0.24 & 0.11 & 0.92 \\
\hline Zone (South west dummy) & $0.47^{\star}$ & 1.99 & $-0.14^{* *}$ & 2.02 & $-0.02^{\star *}$ & -2.18 \\
\hline Zone (South east dummy) & $0.13^{* * *}$ & 4.48 & $0.02^{* *}$ & 2.42 & $0.09^{* * *}$ & 3.13 \\
\hline Zone (South south dummy) & $0.18^{* * *}$ & 2.56 & $0.33^{* * *}$ & 5.13 & $0.26^{* * *}$ & 2.98 \\
\hline $\begin{array}{l}\text { Constant } \\
\text { F-Value } \\
\text { Prob }>\text { F }\end{array}$ & $\begin{array}{l}1.63^{* * *} \\
116.34^{\star * *} \\
0.000\end{array}$ & 3.28 & $\begin{array}{l}1.18^{* * *} \\
132.82^{* * *} \\
0.000\end{array}$ & 41.22 & $\begin{array}{l}1.14^{* * *} \\
156.71^{* * *} \\
0.000\end{array}$ & 44.17 \\
\hline
\end{tabular}


Creative Commons User License: CC BY-NC-ND

Abstracted by: EBSCOhost, Electronic Journals Service (EJS),

Google Scholar, Journal Seek, Scientific Commons,

Food and Agricultural Organization (FAO), CABI and Scopus

http://eoi.citefactor.org/10.11226/v24i3
Journal of Agricultural Extension

Vol. 24 (3) July, 2020

ISSN(e): 24086851; ISSN(Print); 1119944X

http://journal.aesonnigeria.org

http://www.ajol.info/index.php/jae

Email: editorinchief@aesonnigeria.org

that consumption evolves along hierarchical order as income increases. The substantial growth in the real per capita income of the household from agriculture are from related sources or from non-farm sources. Farm households are engaged in some income generating activities with the intention to boost future income and food consumption (Aiyede, Sha and Olawale, 2017). This result might be arising from the additional sources of income that may be accruing to the household in a situation where most of the members of the household are involved in some other income-generating activities apart from farming. Therefore, involvement of household head in non-farm activities improves households' dietary diversity. It thus becomes imperative to give more serious attention to the concerns relating to dietary diversity, particularly given the relationship between farm households' nutritional outcomes and food price shocks in Nigeria.

\section{Conclusion and Recommendations}

On the average, household food consumption variety is fairly high. The observed patterns of food calorie consumption over the years indicate higher consumption during the post-harvest season than in the post-planting periods. Spikes in cereal prices (rice and wheat) are generally, associated with a lower number of meals consumed in a household and a lower likelihood of the number of calories being consumed. However, spikes in the price of wheat are associated with higher dietary diversity. As a food deficit and wheat and rice importing country, food prices in Nigeria are closely linked to global prices and price shocks. Hence, excessive international as well as domestic food price variability is a concern for domestic food security. Households with high income and educational status can substantially raise calorie consumption, the real value of food consumed and dietary diversity. Spikes in the price of cereals generally hold negative consequences for food quantity consumption (in terms of calorie and real value of food consumed), and affect dietary diversity of households. Increases in the price of nonfood items could advance the real value of food intake of households. Beyond, increased consumption of food calories, greater access to higher education and income seems likely to enhance food consumption diversity and the real value of food consumed by the household. Therefore, income and education improvement is crucial for raising food calories and satisfaction of hunger needs among households. A combination of policy strategies, including income growth, agricultural development and targeted food distribution programs could reduce the problems of inadequate calorie consumption among farm households.

\section{References}

Abbasi, N., Ghoochani, O. M., Ghanian, M., \& Kitterlin, M. (2016). Assessment of households' food insecurity through use of a USDA questionnaire. Adv Plants Agric Res, 4(5), 1-8. 
Creative Commons User License: CC BY-NC-ND

Abstracted by: EBSCOhost, Electronic Journals Service (EJS),

Google Scholar, Journal Seek, Scientific Commons,

Food and Agricultural Organization (FAO), CABI and Scopus

http://eoi.citefactor.org/10.11226/v24i3
Journal of Agricultural Extension

Vol. 24 (3) July, 2020

ISSN(e): 24086851; ISSN(Print); 1119944X

http:///ournal.aesonnigeria.org

http://www.ajol.info/index.php/jae

Email: editorinchief@aesonnigeria.org

Adekunle, C. P. (2020). Welfare Effects of Food Price Changes on Farm Households in Nigeria. PhD Thesis, Department of Agricultural Economics and Farm Management, Federal University of Agriculture, Abeokuta, Ogun State, Nigeria.

Agada, M. O. and Igbokwe, E. M. (2015). Dietary diversity of rural households in North Central Nigeria. European Journal of Nutrition and Food Safety, 5 (3):150-55. doi:10.9734/EJNFS.

Aiyede, E. R., Sha, P. D., \& Olawale, E. (2017). Public policy, intergovernmental politics and the piloting of cash transfers in Nigeria. In Politics, Public Policy and Social Protection in Africa (pp. 84-105). Routledge.

Akerele, D. (2015). Household food expenditure patterns, food nutrient consumption and nutritional vulnerability in Nigeria: Implications for Policy. Ecology of Food and Nutrition 54 (5):546-71. doi:10.1080/03670244.2015.1041136.

Akerele, D., Sanusi, R. A., Fadare, O. A., \& Ashaolu, O. F. (2017). Factors influencing nutritional adequacy among rural households in Nigeria: How does dietary diversity stand among influencers?. Ecology of food and nutrition, 56(2), 187-203.

Akombi, B. J., Agho, K. E., Hall, J. J., Merom, D., Astell-Burt, T., \& Renzaho, A. M. (2017). Stunting and severe stunting among children under-5 years in Nigeria: A multilevel analysis. BMC pediatrics, 17(1), 15.

Alem, Y. (2015). Poverty persistence and intra-household heterogeneity in occupations: Evidence from urban Ethiopia. Oxford Development Studies, 43(1), 20-43.

Baker, S. R. (2015). Debt and the consumption response to household income shocks. Available at SSRN 2541142.

Bühler, D., Grote, U., Hartje, R., Ker, B., Lam, D. T., Nguyen, L., \& Tong, K. (2015). Rural livelihood strategies in Cambodia: Evidence from a household survey in Stung Treng. Available at SSRN 2583770.

Central Bank of Nigeria (2018). Central Bank of Nigeria annual statistical bulletin. Available at https://www.cbn.gov.ngl.

D'Souza, A., \& Jolliffe, D. (2016). Coping with food price shocks in Afghanistan. In Food Price Volatility and Its Implications for Food Security and Policy (pp. 543581). Springer, Cham.

Daniel, C. (2016). Economic constraints on taste formation and the true cost of healthy eating. Social Science \& Medicine, 148, 34-41. 
Creative Commons User License: CC BY-NC-ND

Abstracted by: EBSCOhost, Electronic Journals Service (EJS),

Google Scholar, Journal Seek, Scientific Commons,

Food and Agricultural Organization (FAO), CABI and Scopus

http://eoi.citefactor.org/10.11226/v24i3
Journal of Agricultural Extension

Vol. 24 (3) July, 2020

ISSN(e): 24086851; ISSN(Print); 1119944X

http:///ournal.aesonnigeria.org

http://www.ajol.info/index.php/jae

Email: editorinchief@aesonnigeria.org

Desiere, S., D'Haese, M., \& Niragira, S. (2015). Assessing the cross-sectional and inter-temporal validity of the Household Food Insecurity Access Scale (HFIAS) in Burundi. Public Health Nutrition, 18(15), 2775-2785.

Egwuma, H., Ojeleye, O. A., \& Adeola, S. S. (2019). What determines food price inflation? evidence from Nigeria. Fuoye Journal of Agriculture and Human Ecology, 1(2), 48-61

Famine Early Warning Systems Network (2017). Sierra Leone Livelihood Baseline Profiles. Available at http://www.fews.ne t/sites/def ault/files/documents/reports/SLNationalOverview_Report_2017HEA_baselines.p $d f$.

Farayibi, A., \& Owuru, J. (2016). Linkage between Fiscal Policy and Poverty Reduction in Nigeria. Available at SSRN 2856545.

Food and Agriculture Organization (2017). The state of food security and nutrition in the world 2017: Building resilience for peace and food security. Retrieved from http://www.fao.org/3/a-i7695e.pdf. Accessed June 2018

Freire, T., \& Rudkin, S. (2019). Healthy food diversity and supermarket interventions: Evidence from the Seacroft Intervention Study. Food Policy, 83, 125-138.

Genoni, M. E., Baez, J. E., \& Salazar, M. (2015). Gone with the storm: Rainfall shocks and household well-being in Guatemala (Vol. 8792, pp. 1-37). IZA Discussion Paper.

Ghosh-Jerath, S., Singh, A., Lyngdoh, T., Magsumbol, M. S., Kamboj, P., \& Goldberg, G. (2018). Estimates of indigenous food consumption and their contribution to nutrient intake in Oraon Tribal Women of Jharkhand, India. Food and nutrition bulletin, 39(4), 581-594.

Grabowski, R., \& Self, S. (2016). Staple food price instability and structural change: Indonesian experience. Journal of Asian Economics, 47, 35-44.

Harttgen, K., Klasen, S., \& Rischke, R. (2016). Analyzing nutritional impacts of price and income related shocks in Malawi: Simulating household entitlements to food. Food policy, 60, 31-43.

Headey, D. D., \& Martin, W. J. (2016). The impact of food prices on poverty and food security. Annual review of resource economics, 8, 329-351.

Hirvonen, K., Taffesse, A. S., \& Hassen, I. W. (2016). Seasonality and household diets in Ethiopia. Public Health Nutrition, 19(10), 1723-1730. 
Creative Commons User License: CC BY-NC-ND

Abstracted by: EBSCOhost, Electronic Journals Service (EJS),

Google Scholar, Journal Seek, Scientific Commons,

Food and Agricultural Organization (FAO), CABI and Scopus

http://eoi.citefactor.org/10.11226/v24i3
Journal of Agricultural Extension

Vol. 24 (3) July, 2020

ISSN(e): 24086851; ISSN(Print); 1119944X

http:///ournal.aesonnigeria.org

http://www.ajol.info/index.php/jae

Email: editorinchief@aesonnigeria.org

Jolliffe, D., Seff, I. J. and De La Fuente, A. (2018). Food Insecurity and Rising Food Prices: What do we learn from experiential measures? Policy Research Working Paper; No. 8442. World Bank, Washington, DC.

Juarez-Torres, M. (2015). The impact of food price shocks on consumption and nutritional patterns of urban Mexican households (No. 1008-2016-80005).

Kalkuhl, M. (2016). How strong do global commodity prices influence domestic food prices in developing countries? A global price transmission and vulnerability mapping analysis. In Food price volatility and its implications for food security and policy (pp. 269-301). Springer, Cham.

Kharas, H., Hamel, K. \& Hofer, M. (2018). The start of a new poverty narrative. Blog. Future Development at Brookings, 19 June (www.brookings.edu/blog/futuredevelopment/2018/06/19/ the-start-of-a-new-poverty-narrative/).

Kim, B. R., Shin, J., Guevarra, R., Lee, J. H., Kim, D. W., Seol, K. H., . \& Isaacson, R. E. (2017). Deciphering diversity indices for a better understanding of microbial communities. J. Microbiol. Biotechnol, 27(12), 2089-2093.

Obwanga, B., Rurangwa, E., van Duijn, A. P., Soma, K., \& Kilelu, C. W. (2018). A comparative study of aquaculture sector development in Egypt, Ghana and Nigeria: Insights and lessons for Kenya (No. 006). Wageningen Marine Research.

Ogundari, K. (2017). Categorizing households into different food security states in Nigeria: the socio-economic and demographic determinants. Agricultural and Food Economics, 5(1), 8.

Onyewuchi, I. (2016). Nigerians spend 73 percent of income on food, beverages. The Guardian. Retrieved from https://guardian.ng/news/nigerians-spend-73-per-centof-income-on-food-beverages/

Pauzé, E., Batal, M., Philizaire, Y., Blanchet, R., \& Sanou, D. (2016). Determinants of diet quality among rural households in an intervention zone of Grande Anse, Haiti. Food security, 8(6), 1123-1134.

Rehman, F. U., \& Khan, D. (2015). The determinants of food price inflation in Pakistan: An econometric analysis. Advances in Economics and Business, 3(12), 571-576.

Rischke, R. (2015). Predicting welfare effects of food price shocks. A comparative analysis. Global Food Transformation of Global Agri-Food Systems: Trends, Driving Forces, and Implications for Developing Countries. Global Food Discussion Papers No. 66 
Creative Commons User License: CC BY-NC-ND

Abstracted by: EBSCOhost, Electronic Journals Service (EJS),

Google Scholar, Journal Seek, Scientific Commons,

Food and Agricultural Organization (FAO), CABI and Scopus

http://eoi.citefactor.org/10.11226/v24i3
Journal of Agricultural Extension

Vol. 24 (3) July, 2020

ISSN(e): 24086851; ISSN(Print); 1119944X

http://journal.aesonnigeria.org

http://www.ajol.info/index.php/jae

Email: editorinchief@aesonnigeria.org

Roser, M and Ortiz-Ospina, E. (2017). Global extreme poverty. Our world in data. Retrieved from: 'https Rising cost of food prices and food insecurity in Nigeria and its implication for poverty reduction://ourworldindata.org/extreme-poverty'.

Shittu, A.M., Akerele, D. and Haile, M. (2018). Effects of Food Price Spikes on Household Welfare in Nigeria. ZEF-Discussion Papers on Development Policy No. 248. Article in SSRN Electronic Journal in January 2018.

Sibhatu, K. T., \& Qaim, M. (2017). Rural food security, subsistence agriculture, and seasonality. PloS one, 12(10).

Tadasse, G., Algieri, B., Kalkuhl, M., \& Von Braun, J. (2016). Drivers and triggers of international food price spikes and volatility. In Food price volatility and its implications for food security and policy (pp. 59-82). Springer, Cham.

Tian, X., \& Yu, X. (2015). Using semiparametric models to study nutrition improvement and dietary change with different indices: The case of China. Food Policy, 53, 6781.

Vadiveloo, M., Parkeh, N., \& Mattei, J. (2015). Greater healthful food variety as measured by the US healthy food diversity index is associated with lower odds of metabolic syndrome and its components in US adults. The Journal of nutrition, 145(3), 564-571.

Von Grebmer, K., Bernstein, J., Prasai, N. Yin, S. and Yohannes, Y. (2015). Global Hunger Index: Armed conflict and the challenge of hunger. International Food Policy Research Institute and Concern Worldwide. Available at http://www.ifpri.org/publication/2015-global-hungerindex-armed-conflict-andchallenge-hunger.

Weber, R. (2015). Welfare Impacts of Rising Food Prices: Evidence from India (No. 1008-2016-80198).

Yu, X., \& Shimokawa, S. (2016). Nutritional impacts of rising food prices in African countries: A review. Food security, 8(5), 985-997. 